\title{
GOD APPEARS IN ALL: JULIAN BARNES' A HISTORY OF THE WORLD IN 10¹/2 CHAPTERS
}

\author{
Pradeepa, M11. and Shobha Ramaswamy² \\ ${ }_{1}^{1}$ Department of Education, Avinashilingam Institute for Home Science and Higher Education for Women, Coimbatore. \\ 2Department of English, Kongunadu Arts and Science College, Coimbatore. \\ Email: deepadesh25@gmail.com; ramaswamy.shobha@gmail.com
}

\begin{abstract}
The creator of nature, the God is the Father of all, the Creator of the Universe and the Supreme Deity. He is also the Father of Jesus Christ and Saviour to His followers. God is seen in many ways, through miacles, such as the appearance of the butterfly when a crew is desperately lost at sea, the rainbow as a covenant to Noah, the actions of the raven and the dove. The present paper focuses on the presence of God in The History of the World in 101/2 Chapters by the contemporary British novelist, Julian Patrick Barnes. The novel with ten and a half chapters represents the trust and faith towards the Supreme Power by means of water. Barnes refers Him directly, indirectly or through the use of metaphor in every story of the novel. The paper draws attention on the actions of the God in the chapters of the novel with regard to nature.
\end{abstract}

Keywords: God, Nature, metaphor.

Julian Barnes, in his novel, The History of the World in 101/2 Chapters, represents the creator of the huge ecosystem, the God and the deluges those happen at the seas. The animals, behemoths, mankind are read between the historical and modern periods.

The book begins with the nature-creator. God referred throughout the novel by Barnes, appears to be the Christian ideal of God although other faiths and cultures are mentioned. In the Christian view, God is the Father of all, the Creator of the Universe, and the Supreme Deity. God is also the father of Jesus Christ, Lord and Savior to His followers.

God may be seen in many ways, through miracles, such as the appearance of the butterfly when a crew is desperately lost at sea, the rainbow as a covenant to Noah, the actions of the raven and the dove. It was God that spoke to Noah about the Great Flood and instructed him to build the Ark. The woodworm had differing tales than Noah, but along the line all seemed to agree that God had some part in the ark building as well as getting everyone and thing that was left safely to shore.

God's wrath may also be seen in regards to the Great Flood or the Great Deluge that completely flooded the earth, except for a select number of animals and the family of Noah. It can also be seen in the violent weather and bad luck that befalls certain people.
He is referred to in every story whether it is directly, indirectly, or through the use of metaphor. In many of the stories it is clear that God is being referenced directly. This is seen mainly in the discussions of religion, such as in "The Wars of Religion." It is also made clear in the tales directly involving Noah's Ark - "The Stowaway", "The Mountain" and "Project Ararat."

Noah was the one chosen by God to save the animals and humans from the Great Flood. Noah was said to be sage, holy, and basically beyond reproach, therefore being the perfect choice to carry out the grand mission. Noah was instructed to build an ark and take aboard his family and two of every type of animal so that the planet could be re-inhabited without the wickedness of those left behind.

The author sees a different side of Noah, and certainly one less flattering than the one in the Bible and other texts. Noah's character is brought into question by the narrator who obviously was not fond of the man. "Noah - what point is there in not telling you the truth? - was bad-tempered, smelly, unreliable, envious, and cowardly." (HWC 16)

The sea is the setting used in all of the stories, at least in part. When one refers to the sea, it often means an ocean or other large body of water which may be another type of body of water. The sea is the greatest enigma on earth. It is a paradox in that it can be gentle and beautiful or violent and ugly. Its creatures are too vast to be counted. The perfect example of this can be seen in "The Shipwreck". The crew of the Medusa first encounters a school of porpoises and later experiences the great strength of 
a deadly shark. The sea is the giver of life to thousands of species of creatures, yet it cannot or will not support mankind.

Although some of the sailors throughout the stories are seasoned navigators, others are not. In the case of Noah, the time at sea was not several months but $5 \frac{1}{2}$ years, according to the woodworm. Others tossed themselves into the sea either on purpose or through some unfortunate accident. It is clear that the sea was not always accommodating to those not native to its waters.

Arghuri appears in "Stowaway", "The Mountain", and "Project Ararat". This location is where the people from Noah's Ark settled after the end of the Great Flood. It is also a town visited by many on the way to Mount Ararat.

The island of Aix appears in" "Shipwreck", "The Mountain" is the port in France where the sailors of the Medusa set sail in 1817.

Medusa appears in "Shipwreck" in which the ship sailed from Aix. The ship, part of a four ship flotilla, ended up in a shipwreck immortalized by Gericault.

Greece appears in "The Visitors" that is the final destination of the Aphrodite Cultural Tour led by guest lecturer, Franklin Hughes.

Ararat which appears in "The Stowaway", "The Mountain," is the mountain on which Noah's Ark supposedly settled. For thousands of years people have made pilgrimages to the site.

The natural ecosystem, the God and the sea (water) are related with mankind right from Noah's period till date. This has been depicted by Barnes with the aspect of interpretation of the natural history. The author presents the induction of various animals and human kinds of a different era in the novel. This showcases diversified natural ecosystems that could be seenrepresented all through the novel in huge deluges and other catastrophes.

\section{REFERENCE}

Barnes, Julian. 2009. A History of the World in 101/2 Chapters. London: Vintage Publishers. 